\title{
SOME REFLECTIONS ON URBAN DUALISM IN MATURE ECONOMIES
}

\author{
David L. McKeE*
}

Many economists will recall with a certain amount of nostalgia the "Robinson Crusoe Dilemma" as it was presented to them in courses in economic theory during their undergraduate days. No doubt these same economists will be surprised to learn that Robinson Crusoe is very much alive and still marooned in small town America. Unfortunately this time it will take much more than a raft to solve his dilemma, for the evidence appears to suggest that he was torpedoed rather than shipwrecked and that his attacker, a peculiar form of dualism, is still at large and ready to sink him should he attempt to rejoin the mainstream. His plight is further complicated by the fact that he has been forgotten by those in the mainstream and is either invisible or unrecognizable to passersby.

Dualism has normally been considered as a condition peculiar to the emerging nations. ${ }^{1}$ In its most general form it reflects the existence of a sophisticated economy superimposed in some fashion upon a traditional economy. Although sometimes considered to be a stage in the developmental process, ${ }^{2}$ it is generally regarded as a pernicious element in the long run-a condition which must be overcome on the road to economic maturity. To date development economists have found dualism to be a formidable adversary able to shift locations and alter appearances and thus build up an immunity from attack in much the same way as a flu virus escapes extinction through mutation. Actually, in a fledgling economy dualism is a disease which affects the growth process.

A mature economy that has been victimized by dualism in its youth will still bear the scars in the form of intra-regional imbalances and pockets of backwardness. The problem is not coextensive with inter-regional imbalances, for dualism does not describe spatially separated economies. The problem is national in scope. Cases where largely rural regions occur, dotted with small towns and plagued by lack of economic vitality, are merely a subset of the main issue.

Even those economies that have grown up unscathed should not be too complacent, for dualism can attack a mature economy. When it does the situation resembles that of an adult affected with a childhood disease. However, the discomfort is often more acute. The initial symptom appears to be poverty. As the disease progresses it attacks the circulatory system of the economy. Vital resources carried by this system are not distributed in an orderly fashion. It is as though certain segments of the economy are getting too much nutrition at the expense of others. The result appears to be bursts of uncontrolled growth in certain parts of the economy and lethargy in others. If the process continues unchecked it will lead to a reversal of economic integration with segments of the economy becoming disoriented. Specifically, there is little room for the small town in a

*Professor of Economics, Kent State University. The author is indebted to two anonymous referees for helpful comments. 
national economy largely geared through its infrastructure to operate in an urban environment.

There are many strains of dualism that can afflict a mature economy. In fact it is becoming increasingly obvious that all of those forms of dualism which have been isolated by developmental economists can occur in the mature economy. The present paper is concerned with dualism as it has arisen out of the urbanization process. Even this type can be broken down into various subcategories. The most obvious of these is the intra-urban variety which afflicts large urban areas. ${ }^{3}$ The major difference in this particular subcategory, as between mature and less sophisticated economies, is probably its positioning within the conurbation. In the emerging nations intra-urban dualism tends to be a problem of the urban perifery. As such it tends to interfere with the orderly expansion of the metropolis. In mature nations the disadvantaged sector of the urban economy tends to create problems in the central city. It is characterized by declining neighborhoods, slums, and, of course, the accompanying social problems that one would expect. It results in declining land values, a flight of the tax base, and in general an exodus of the middle class from the central city. This results in explosive growth in the suburbs-hence the phenomena known as urban sprawl. ${ }^{4}$ Thus while intra-urban dualism tends to be a constricting element in the fledgling economy, it is an explosive force in the mature economy-causing cities to expand in an uncontrolled fashion.

A second form of dualism which is related to the process of urbanization is technological dualism. ${ }^{5}$ The urban industrial areas tend to syphon the potential away from the rural segment of the economy. ${ }^{6}$ As Professor Hoselitz has suggested, the more advanced sectors of an economy are usually associated with urban industrial complexes. ${ }^{7}$ This implies circular causation à la Gunnar Myrdal-in other words, a system of haves and have nots based upon industrial concentration in certain urban complexes. ${ }^{8}$

Although rural poverty is a concept familiar to most economists it seems as though a particular aspect of the problem has been overlooked. Specifically, little attention has been given to the plight of the small town and its inhabitants, who do not enjoy a standard of living comparable to the average resident of the larger urban agglomerations. Their plight has gone unnoticed because the small town has always been a romantic part of the American heritage, and in some ways small town living is a state of existence which is envied by many who have left it behind-not in the sense that they would ever return to it, but rather they feel that those who are still there have opted for that existence, with full knowledge of the financial trade-offs involved.

This view is an oversimplification. The patterns of urbanization within a country are as diverse as the structure of the nation's economy. Urban units form an essential part of the physical plant within which the economy is constructed. This has been recognized by exponents of economic base analysis-a system of thought which equates both urban expansion and the continued viability of urban complexes with the success of export activities located within them. ${ }^{9}$ In other words, the local economy relies upon linkages exterior to it for its continued profitability. Should it ever become unplugged this circumstance is quickly impressed upon the local residents in the form of declining economic opportunities, increased unemployment and deteriorating material welfare levels. 
Small town America is becoming unplugged. Advances in transportation and communication have upset the old role of the urban hierarchy. The functions of small market towns have been eclipsed by larger centers. Industry and commerce have grown in those centers, while the smaller towns have tended to stagnate. Concentration was a natural offshoot of the pursuit of profitable business opportunities. The larger cities contained the labor pools, the specialized services, the potential markets and various other economies of scale which contributed to industrial and commercial growth and concentration.

Today advances in communications have made such concentration less necessary, but the mere fact that large agglomerations exist with their locked in resources and a national infrastructure to service their needs rules out the serious consideration of economic decentralization as a viable strategy at the national level. Attempts at decentralization in Britain and France have met with questionable success. ${ }^{10}$ In any case those policies were designed to alleviate pressures in London and Paris and certainly were not conceived as a vehicle for alleviating variations in economic opportunity between large and small urban areas.

In the United States today the business of the national economy is conducted within a system of large metropolitan areas through appropriate transportation and communication linkages. This system has been superimposed upon the previously existent urban hierarchy. The older system has been bypassed rather than phased out. An urban hierarchy still exists with villages, small market towns, regional service centers and larger centers of various sizes which possess functions transcending regional boundaries. The top of the hierarchy has retained its relevance to the national economy while smaller centers which catered to largely local needs have not. Today the market mechanism has focused attention upon various megalopolitan areas at the expense of smaller centers. The latter have been eclipsed by the glamour and activity of the former. More and more the bulk of industrial and commercial activity is becoming concentrated in vast urban agglomerations; and, to use an earlier analogy, the circulatory system of the economy is undergoing a change. The larger centers are getting too much nutrition while the smaller centers are being stifled.

Small towns are the most seriously affected. It appears as though they are no longer a part of the national economy. Goods and services flow back and forth between the large urban complexes while the plight of the small towns becomes more and more serious. This is a form of economic dualism which has arisen in the advanced nations. To retain a place in the national economy a center must have something to offer which transcends local needs. Failing in this, its inhabitants may be aware of material advances at the national level, yet they cannot hope for a proportional share in the benefits.

Generally speaking, they live in older housing, possess fewer up-to-date household goods, and work for lower wages. Many tasks are still performed by households which have long since been taken over by the service sector in larger centers. The commercial sector is characterized by considerable disguised unemployment, and storekeepers are caught in a dichotomy. Their sales volume would not justify the hours they work, and yet they must keep open due to the personal significance of marginal sales. Meanwhile they continue to loose business to larger centers. 
One might expect that the plight of the small center would be less severe the further it is from the larger agglomeration. This is an over-simplification, for while it is true that its sphere of influence will be more definite and it may enjoy a captive market, its relative position within the national economy is declining. It is as though there are two economies in operation-one based in the larger cities and the other-perhaps traditional in a relative sense-composed of remnants of an urban hierarchy which is marooned and out of phase with the national economy.

Individuals within the traditional economy are victims of the Robinson Crusoe dilemma. In fact, these contemporary Crusoes are in much more serious straits than was their Defoian predecessor. Their plight is not recognized by society in general. As a consequence, they can expect no search parties and very little assistance. Assuming they do find their way to a larger center, they may discover that they have been away too long. In other words, their education and experience does not provide them with the skills that they require in their sophisticated new environment. As a consequence, they become a part of the disadvantaged portion of the urban economy, and this contributes to the problem of intra-urban dualism.

If they decide to remain in the smaller towns they are still less fortunate in many ways than was the original Crusoe. At least he was able to improve his lot over time, whereas his modern counterparts are falling behind relative to the rest of the economy. There is little evidence to support a reversal of this trend. In fact, the smaller centers are becoming more and more isolated from the mainstream of economic life.

Current data relating to urbanization, together with predictions concerning future trends, tend to obscure the plight of the smaller urban areas. Predictions concerning the percentage of the population that will be urbanized may be used to suggest the demise of rural poverty. They may also suggest more problems for the larger metropolitan areas. They do not reveal the plight of the smaller towns. These towns are not showing any tendency to disappear, except through absorption by larger centers, and they are showing little potential for becoming viable local economies. In addition to a wastage of human resources and related problems referred to above, there is a waste of capital due to lack of mobility. The residents of these towns have investments in their homes and other facilities, and the physical plants of the towns themselves must also be considered. The people are locked in because of investments in property which often cannot be recouped. Thus in many cases migration to areas with greater potential is not an acceptable solution on the personal level.

The prognosis suggests that this form of dualism, a system of haves and have nots based upon size, will sustain itself. The traditional urban hierarchy can no longer be relied upon to distribute profit motivated opportunities to urban areas of all sizes. Returning to the medical analogy, its circulatory system has broken down. Perhaps a second malady is present-the large metropolitan areas are displaying symptoms of explosive growth while growth in other centers has been stunted. This would suggest that the problem lies with the pituitary, and a possible prescription might include a cutback of growth hormones for megalopolitan areas, and at least more study with respect to their applicability to smaller centers. 
This line of reasoning borders on the optimum city size debate ${ }^{11}$ and will not resolve the problem discussed in this paper. If the major metropolitan areas are too large-a point which has yet to be demonstrated-and the planners succeed in stabilizing them by redirecting economic activity to smaller cities, the small towns will still be spectators. If they are to be reabsorbed into the national economy ways must be found for the profitable location of industry within them. Although the concentration of industry is no longer as necessary as it once was, firms that are willing to locate in small towns would have to be assured that they will have access to the very national transportation and communications networks that have arisen in a manner excluding the small towns. Obviously the solution is beyond the capabilities of local authorities and their traditional attempts at industrial park development and tax concessions. The problem, if it is to be dealt with, will involve national planning and cooperation between various levels of government. Failing in this, the only road towards improving the lot of the small town may be through an expansion of the service sector in response to demand created through a demonstration effect through the national communications media. If this is to be the solution then it is fortunate that the modern Crusoe is a patient person.

\section{FOOTNOTES}

1. See J. H. Boeke, Economics and Economic Policy of Dual Societies (New York: Institute of Pacific Relations, 1953).

2. See, for instance, John C. H. Fei and Gustav Ranis, "Agrarianism, Dualism, and Economic Development," The Theory and Design of Economic Development, ed. by Irma Adleman and Erik Thorbecke (Baltimore: The Johns Hopkins Press, 1966), pp. 3-41.

3. David L. McKee and William H. Leahy, "Intra-Urban Dualism in Developing Economies," LandEconomics, Vol. XLVI, No. 4, November, 1970 , pp. 486-488.

4. See David L. McKee and Gerald H. Smith, "Environmental Diseconomies in Suburban Expansion," The American Journal of Economics and Sociology, Vol. XXXI, No. 2, April 1972, pp. 181-188.

5. W. A. Lewis, The Theory of Economic Growth (Homewood: Richard D. Irwin, Inc., 1955) Chapter 4. See also John C. H. Fe and Gustav Ranis, Development of the Labor Surplus Economy: Theory and Policy (Homewood: Richard D. Irwin, Inc. 1964).

6. See David L. McKee and William H. Leahy, "Urbanization, Dualism, and Disparities in Regional Economic Development," Land Economics, Vol. XLVI, No. 1, February, 1970, pp. 82-85 and David L. McKee, "Regional Inequality and the Market Mechanism-A Comment," Kyklos, Vol. XXVI-1973-FASC. 3, pp. 624-626.

7. See, for example, Bert F. Hoselitz, Sociological Aspects of Economic Growth (Glencoe: The Free Press, 1960), p. 159.

8. Gunnar Myrdal, Economic Theory and Underdeveloped Regions (London: Gerald Duckworth and Company Ltd., 1957), pp. 26-42.

9. For a selection of articles on the subject consult Ralph W. Pfouts (ed.), The Techniques of Urban Economic Analysis (West Trenton: Chandler Davis Publishing Company, 1960).

10. See, for instance, Lloyd Rodwin, Nations and Cities: A Comparison of Strategies for Urban Growth (Boston: Houghton Mifflin Company, 1970), Chapters V and VI.

11. See Harry W. Richardson, The Economics of Urban Size (Lexington, Mass.: Lexington Books, D.C. Heath \& Co., 1973). 